\title{
Development and validation of a rapid turbidimetric assay to determine the potency of norfloxacin in tablets
}

\author{
Lucas Chierentin*, Hérida Regina Nunes Salgado
}

\author{
School of Pharmaceutical Sciences, University of the State of São Paulo “Júlio de Mesquita Filho”, Araraquara, São Paulo, \\ Brazil
}

\begin{abstract}
Norfloxacin is one of the first commercially available (and most widely used) fluoroquinolone antibiotics. This paper reports the development and validation of a simple, sensitive, accurate and reproducible turbidimetric assay method to quantify norfloxacin in tablets formulations in only 4 hours. The bioassay is based on the inhibitory effect of norfloxacin upon the strain of Staphylococcus epidermidis ATCC 12228 IAL 2150 used as test microorganism. The assay was performed $3 x 3$ parallel lines like, three tubes for each concentration of reference substance and three tubes for each sample concentration. The results were treated statistically by analysis of variance and were found to be linear $\left(r^{2}=0.9999\right)$ in the selected range of $25-100 \mu \mathrm{g} \mathrm{mL}^{-1}$; precise (intra-assay: relative standard deviation $(\mathrm{RSD})=1.33 \%$; inter-assay: $\mathrm{RSD}=0.21 \%)$, accurate $(100.74 \%)$ and robust with RSD lower than $4.5 \%$. The student's $t$-test showed no statistically significant difference between the proposed turbidimetric method and an HPLC method previously validated. However the turbidimetric assay can be used as a valuable alternative methodology for the routine quality control of this medicine, complementary to other physical-chemical methods.
\end{abstract}

Uniterms: Microbiological assay. Quality control. Norfloxacin/quantification in tablets. Turbidimetric method/quality control/validation. Antimicrobials/quality control.

\begin{abstract}
O norfloxacino foi a primeira fluorquinolona (e mais utilizada) disponível no mercado. Este trabalho divulga um novo desenvolvimento e validação de um método turbidimétrico simples, sensível, preciso e reprodutível para a quantificação de norfloxacino em comprimidos em apenas 4 horas. O bioensaio é baseado no efeito inibitório de norfloxacino sobre a cepa Staphylococcus epidermidis ATCC 12228 IAL 2150, utilizada como micro-organismo teste. O bioensaio foi efetuado através do delineamento de linhas paralelas $3 \times 3$, em que três tubos foram utilizados para a solução padrão e três tubos para as concentrações da amostra. Os resultados foram tratados estatisticamente pela análise de variância, apresentando coeficiente de correlação linear de $r^{2}=0,9999$, na faixa de 20 a $100 \mu \mathrm{g} \mathrm{mL} \mathrm{m}^{-1}$; precisão (intra-ensaio: desvio padrão relativo (RSD) $1,33 \%$; inter-ensaio: $R S D=0,21 \%$ ), exatidão $(100,74 \%)$ e robustez com RSD menor que $4,5 \%$. O teste- $t$ mostrou não haver diferença estatisticamente significativa entre o método turbidimétrico proposto e um método por HPLC previamente validado. No entanto, o ensaio turbidimétrico pode ser utilizado como método alternativo para o controle de qualidade de rotina para este antimicrobiano, como um complemento de outros métodos físico-químicos.
\end{abstract}

Unitermos: Ensaio microbiológico. Norfloxacino/quantificação em comprimidos. Método turbidimétrico/ controle de qualidade/validação. Antimicrobianos/controle de qualidade.

\section{INTRODUCTION}

Norfloxacin (1-ethyl-6-fluoro-1,4-dihydro-4-oxo7-(1-piperazinyl)-3-quinoline carboxylic acid) with a molecular weight of $319.33 \mathrm{~g} \mathrm{~mol}^{-1}$ (Figure 1), is a

\footnotetext{
*Correspondence: Lucas Chierentin. School of Pharmaceutical Sciences. São Paulo State University. Rodovia Araraquara-Jaú, km 1 - 14801-902 - Araraquara - SP, Brazil. E-mail: 1czenith@gmail.com
}

synthetic antibiotic from the fluoroquinolone family (Well et al., 1998; Lu et al., 2012). It belongs to the second generation of fluoroquinolones, which are characterized by a somewhat broader spectrum of activity against Gram-negative pathogens such as Escherichia coli, Klebsiella spp., Pseudomonas spp., Salmonella spp., and Campylobacter spp however Gram-positive pathogens such as Staphylococcus aureus, Streptococcus faecalis and Actinobacillus spp. are more susceptible to this drug than 
first generation quinolone members differing in a fluorine atom at the 6 th position and a piperazine moiety at the 7 th position (Pohlhaus, Kreuzer, 2005; Deng, Su, Kang, 2006).

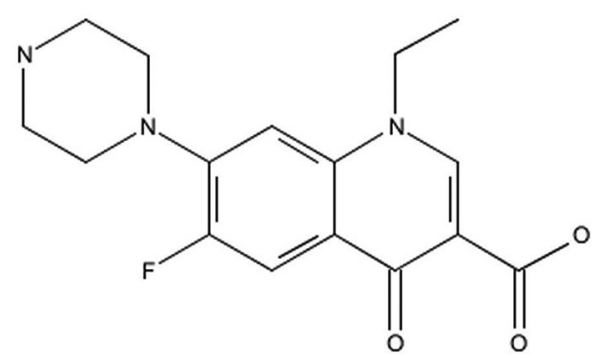

FIGURE 1 - Chemical structure of norfloxacin (CAS 7045896-7).

The mechanism of action of norfloxacin involves inhibition of type II topoisomerase (DNA gyrase) which is essential for DNA replication and its use leads to double-stranded DNA break and cell death. Norfloxacin is widely used for the treatment of bacterial infections of the urinary tract, gastrointestinal tract infections and the respiratory tract (Cordoba, Cordoba, Bernabe, 1996; Liu et al., 2011). Norfloxacin has a relatively broad spectrum of antimicrobial activity, excellent tissue penetration and exerts bacterial action in low concentrations, often at a minimum inhibitory concentration (MIC) of less than 0.1 $\mu \mathrm{g} \mathrm{mL}^{-1}$ (Fernandes, 1988; Pavithra, Prakash, Jayakumur, 2010).

For the determination of norfloxacin in biological fluids the literature reports physicochemical methods such as liquid chromatography (Guo et al., 2005), capillary electrophoresis (Liu, Jia, Tian, 2008), polarography (Lin, Zeping, Yuzhen, 2000) and volumetric analysis (Baraza, 1985; Shen, Wang, Liu, 1993; Gu et al., 1994). Microbiological methods for norfloxacin evaluation in pharmaceutical preparations were found in the literature (Farmacopeia Brasileira, 2001), which uses Staphylococcus epidermidis using an agar diffusion method. In previous work Froehlich and coworkers used Bacillus subtilis in agar diffusion method by cylinders and plate (Froehlich, Schapoval, 1990). An important advantage of turbidimetric assay is that the drug in the study can be dissolved to a higher extent. Traditional microbiological assays for antibiotics which are based upon the inhibition of growth of a sensitive microorganism require incubation times of 18-24 h (Simpson, Kobos, 1984), therefore, the amount of time required for a microbiological assay can be significantly reduced by a turbidimetric test that requires only $4 \mathrm{~h}$.

Microbiological turbidimetric assays are generally low cost assays and moreover, simple procedures of bioassays have allowed them to become an alternative methodology for drug potency assessment in pharmaceutical formulations. In addition, bioassay is an ecological technique because it is not a residue or solvent procedure. The aim of the present study was to develop and validate a simple, sensitive, precise, accurate and rapid microbiological assay by the turbidimetric method to quantify norfloxacin in tablets as a new alternative to the physicochemical methods described in the literature.

\section{MATERIAL AND METHODS}

\section{Standard and reagents}

Norfloxacin reference standard (purity 100\%) and pharmaceutical product norfloxacin tablet with a label claim of $400 \mathrm{mg}$ drug was obtained from União Química (Pouso Alegre, Brazil). Sodium hydroxide $(\mathrm{NaOH})$ was obtained from Synth (São Paulo, Brazil). All reagents used were of the analytical grade. Eluents and reference substance solutions were prepared with high-quality water obtained from a Milli-Q system (Millipore, Milford, MA, USA) for the bioassay.

\section{Norfloxacin reference substance solutions}

Stock solutions were prepared by dissolving $12.5 \mathrm{mg}$ of norfloxacin (reference substance) in $25.0 \mathrm{~mL}$ amber volumetric flask with $5 \mathrm{~mL}$ of $0.1 \mathrm{MNaOH}$ solution, with 30 minutes sonication. The final volume was completed with sterile water. Aliquots of this solution were diluted in sterile water to give concentrations of 25,50 and $100 \mu \mathrm{g} \mathrm{mL}^{-1}$ (S1, S2 and S3, respectively), which were used in the bioassay.

\section{Preparation of sample solutions}

Twenty tablets of norfloxacin were weighed, ground, and mixed. An appropriate amount $(21.91 \mathrm{mg}$ ) was added to $5 \mathrm{~mL}$ of $0.1 \mathrm{M} \mathrm{NaOH}$ sterile solution, with 30 minutes sonication, the final volume was completed with water in a $25 \mathrm{~mL}$ volumetric flask. This solution was filtered using Whatman filter paper $n^{\circ} 1$. Aliquots of this solution were accordingly diluted in sterile water to obtain the concentrations of 25,50 and $100 \mu \mathrm{g} \mathrm{mL}^{-1}$ (T1, T2 and T3, respectively) which were tested against $\mathrm{S} 1, \mathrm{~S} 2$ and $\mathrm{S} 3$.

\section{Microorganism and inoculum}

The cultures of Staphylococcus epidermidis ATCC 12228 IAL 2150 (obtained of Instituto Adolfo 
Lutz, São Paulo, Brazil) were cultured on brain heart infusion (BHI) (Acumedia-USA) at $35^{\circ} \mathrm{C}$ for $24 \mathrm{~h}$. The microorganism standardization was carried out as per the procedure described in the Brazilian and The United States Pharmacopeias (ANVISA, 2010; United States Pharmacopeia, 2012). A diluted culture suspension of $25 \pm 2 \%$ turbidity (transmittance) was obtained with the wavelength set at $580 \mathrm{~nm}$, using a suitable spectrophotometer (Beckman Coulter, CA, USA) and a 10 $\mathrm{mm}$ diameter test tube as an absorption cell against BHI as blank. From this standardized suspension, aliquots of $0.6 \mathrm{~mL}$ were added to each tube.

\section{Turbidimetric bioassay}

Twenty glass tubes $(25 \times 145 \mathrm{~mm})$ were organized in a rack, each tube with $10 \mathrm{~mL}$ of sterile BHI and 0.2 $\mathrm{mL}$ each of reference substance and sample solution. Upon completion of the rack of test solutions, was added $0.6 \mathrm{~mL}$ of inoculum was added to each tube in the rack and the completed rack was immediately placed in an incubator (32 rotation per minute; Shaker-model MA 420 , Marconi, Brazil) water bath maintained at $35^{\circ} \mathrm{C}$. The tubes were incubated for $4 \mathrm{~h}$. After incubation $0.5 \mathrm{~mL}$ of $12 \%$ formaldehyde was added to each tube, taking one rack at time, and its absorbance was read using, a suitable spectrophotometer with the wavelength set at $530 \mathrm{~nm}$. The bioassay was performed $3 \times 3$ parallel lines like, three tubes for each concentration of reference substance and three tubes for each sample concentration (S1, S2 and S3; $\mathrm{T} 1, \mathrm{~T} 2$ and $\mathrm{T} 3$ ), one tube for the positive control (BHI and $0.6 \mathrm{~mL}$ of inoculum), and one tube for the negative control (only $10 \mathrm{~mL}$ of BHI). For each concentration of the reference substance and sample three replicates were made.

\section{Calculation}

To calculate the activity of norfloxacin in tablets, the Hewitt equation was used (Hewitt, 2004). The bioassay was statistically calculated by the linear parallel model and means of regression analysis and verified using analysis of variance (United States Pharmacopeia, 2012).

\section{Method validation}

The developed turbidimetric bioassay method was validated for the following parameters: Linearity, precision, accuracy, specificity, robustness and limit of detection (LOD) and quantitation (LOQ) (ICH, 2005; United States Pharmacopeia, 2012).

\section{Linearity}

The calibration curve was obtained at three concentration levels $\left(25-100 \mu \mathrm{g} \mathrm{mL}^{-1}\right)$ of the reference substance and three doses of sample. The linearity was evaluated by the least square regression method with triplicate determinations at each concentration level.

\section{Precision}

The precision of the bioassay was determined by repeatability (intra-assay) and intermediate precision (inter-assay) and was expressed as the relative standard deviation (RSD). Repeatability was calculated from six replicates of norfloxacin against the norfloxacin reference substance, by the same analyst, under the same experimental conditions on the same day (intra-assay). The intermediate precision was evaluated performing the analysis in the same laboratory on 3 days (inter-assay).

\section{Accuracy}

The recoveries were determined at three concentration levels $(80,100$, and $120 \%)$, by adding known amounts of norfloxacin reference substance to the samples at the beginning of the process. Accurate aliquots of $0.3,0.5$, and $0.7 \mathrm{~mL}$ of the reference substance solution $\left(500 \mu \mathrm{g} \mathrm{mL} \mathrm{m}^{-1}\right)$ were transferred into a $10 \mathrm{~mL}$ volumetric flask together with $0.5 \mathrm{~mL}$ of sample solution $\left(500 \mu \mathrm{g} \mathrm{mL}^{-1}\right)$ and diluted with sterile water to give final concentrations of 40,50 , and $60 \mu \mathrm{g}$ $\mathrm{mL}^{-1}$, respectively. The percentage recovery of norfloxacin reference substance added was calculated.

\section{Specificity}

The specificity of the development method was determined by means of a placebo mixture (talc, lactose, microcrystalline cellulose, povidone, magnesium stearate and sodium croscarmelose).

\section{Robustness}

Robustness was determined by analyzing the same sample under a variety of conditions. The considered factors were incubation time and wavelength. The relative standard deviation (RSD) was calculated.

\section{Limit of detection (LOD) and quantitation (LOQ)}

The LOD and LOQ of norfloxacin by the proposed method were determined using calibration reference. LOD 
and LOQ were calculated as 3 and $10 \sigma / S$, respectively, where $\mathrm{S}$ is the slope of the calibration curve and $\sigma$ is the standard deviation of $y$-intercept of regression equation.

\section{High performance liquid chromatography (HPLC) method}

An HPLC method previously developed and validated by our study group has been chosen as a comparative method for the determination norfloxacin solution. The mobile phase consisted of mixture of $5 \%$ acetic acid aqueous solution and methanol (80:20, v/v). This was found to give sharp peak of norfloxacin at a retention time of $5.7 \mathrm{~min}$. HPLC analysis of norfloxacin was carried out at a wavelength of $277 \mathrm{~nm}$ with a flow rate $1.0 \mathrm{~mL} / \mathrm{min}$, injection volume was $20 \mu \mathrm{L}$ and an Agilent Zorbax ${ }^{\circledR} \mathrm{C}_{18}$ analytical column $(150 \times 4.6 \mathrm{~mm} ; 5 \mu \mathrm{m})$ was used (Chierentin, Salgado, 2013).

\section{RESULTS AND DISCUSSION}

In the turbidimetric bioassay, an experimental $3 \times 3$ design, using three dose levels for each reference substance and sample was used following the procedure described in the Brazilian and United State Pharmacopoeias (Froehlich, Schapoval, 1990; United States Pharmacopeia, 2012; Farmacopeia Brasileira, 2010).

The experimental conditions were adjusted to accurately determine the performance of the assay. Some parameters were tested earlier to establish the conditions described and show in Table I. The strain of Staphylococcus epidermidis ATCC 12228 IAL 2150, was found to be a suitable microorganism that allowed quantitation of norfloxacin. The reason why we choose the $S$. epidermidis was that this microorganism is gram positive and less danger them others. The positive and negative control of the bioassay can be compared in the Figure 2.

The selected range of the doses $(25,50$ and $100 \mu \mathrm{g} \mathrm{mL}^{-1}$ ) was shown to be more appropriate for this assay because a good linear relationship was obtained between the logarithm of the dose and the response, plus slope of the curve. For the linearity, the experimental mean of absorbance for reference solutions were: 0.564 $(\mathrm{RSD}=2.51 \%)$ for low dose, $0.448(\mathrm{RSD}=2.67 \%)$ for medium dose and $0.314(\mathrm{RSD}=1.12 \%)$ respectively. The representative linear equation for norfloxacin standard and norfloxacin sample was $y=-0.18 \operatorname{Ln}(x)+1.1534 ; y=-0.18$ $\operatorname{Ln}(x)+1.1465$, where $x$ is $\operatorname{Ln}$ dose and $y$ is absorbance. The coefficient of regression was $r^{2}=0.9999 ; r^{2}=0.9985$ respectively.
TABLE I - Conditions tested to establish the parameters for turbidimetric assay of norfloxacin

\begin{tabular}{lc}
\hline Parameters & Conditions \\
\hline Standard curve $\left(\mu \mathrm{g} \mathrm{mL}^{-1}\right)$ & $5,10,25,50$ and 100 \\
\hline Diluents solutions & Water, buffer solution $\mathrm{pH} 6.0$ and \\
& 8.0 \\
\hline Microorganism & Staphylococcus aureus \\
& ATCC 6538 IAL 1851 \\
& Staphylococcus epidermidis \\
& ATCC 12228 IAL 2150 \\
& Bacillus subtilis \\
& ATCC 9372 IAL 1027 \\
\hline Culture media & Brain heart infusion and broth \\
& Mueller-Hinton \\
\hline Inoculum (\%) & 4,6 and 10 \\
\hline
\end{tabular}



FIGURE 2 - Positive control (a) and negative control (b) of the bioassay.

The precision of the method was determined by repeatability (intra-assay) and intermediate precision on three different days (inter-assay) and was expressed as RSD (\%) of a series of measurements. The result obtained shows means RSD of $1.33 \%$ and inter-assay precision shows a mean RSD $0.21 \%$ indicating good precision both analysis.

The accuracy of the method was evaluated at 80 , 100 and $120 \%$ of the nominal analytical concentration in the specified range of $25.0-100.0 \mu \mathrm{g} \mathrm{mL}^{-1}$. The mean accuracy was $100.74 \%$ and RSD was $1.55 \%$ (Table II), 
which confirms the ability of the method to determine the norfloxacin concentration with accuracy, indicating an agreement between the true value and the measured value. The specificity of the bioassay was verified with absence of microbial activity in excipients mixture.

The robustness study was carried out by making small changes in wavelength (525 and 535) and incubation time ( $3 \mathrm{~h} 45$ and $4 \mathrm{~h} 15)$. The robustness of the method shows $\%$ RSD value less than $5 \%$ in both small changes (Table III). Robustness tests are normally applied to investigate the effect on either precision or accuracy. It was observed that there were no marked changes in the potency, which demonstrated that turbidimetric bioassay is robust.

LOD and LOQ values for norfloxacin were found to be $0.83 \mu \mathrm{g} \mathrm{mL}^{-1}$ and $2.79 \mu \mathrm{g} \mathrm{mL}^{-1}$, respectively.

Regarding the quality control of medicines, a validated turbidimetric microbiological assay for determination of norfloxacin in pharmaceutical formulations has not been reported yet.

Microbiological methods most commonly used to determine the potency of the antibiotics are the methods of agar diffusion and turbidimetric method (Cardoso, Schapoval, 2000; Bakshi, Singh, 2002; Schmidt et al., 2009; Salgado, Lopes, Lucchesi, 2006; Cazedey, Salgado, 2011; Aléssio, Salgado, 2012; Tótoli, Salgado, 2013; Pedroso, Salgado, 2014). The turbidimetric method has the advantage of being more sensitive and requires shorter analysis time compared with the agar diffusion method as it responds to low concentrations of antimicrobials.
The bioassay method developed for determination of norfloxacin tablets in this study is linear, precise, accurate, specificity, robustness, LOD and LOQ. All RSD value was less than 5\%, according with the guideline.

\section{Comparison of methods}

To our knowledge, no comparative study of HPLC and microbiological methods to measure norfloxacin in tablets has been reported previously. The data obtained by the analysis of NOR in tablets using the microbiological assay were compared with labeled amounts and with HPLC methods (Table VI). For this comparison, the Student's $t$-test was performed, considering a significance level of $5 \%$. Analysis of variance indicated no significant differences between these methods ( $\mathrm{t}_{\text {calculated }} 1.94<\mathrm{t}_{\text {critical }}$ 2.77).

The quantification of antimicrobial components by methods such as HPLC, although precise, cannot provide a true indication of microbiological activity. Attempts to correlate microbiological assay results with those from chemical methods have proved disappointing. Moreover, microbiological assays continue to be an important and essential tool for quality control of antimicrobial agents.

\section{CONCLUSION}

From the results, it can be concluded that the proposed bioassay method was valid and suitable

TABLE II - Experimental values obtained in the recovery test for norfloxacin in tablets by microbiological assay

\begin{tabular}{lccccc}
\hline $\begin{array}{l}\text { Concentration of } \\
\text { sample }\left(\mu \mathrm{g} \mathrm{mL} \mathrm{m}^{-1}\right)\end{array}$ & $\begin{array}{c}\text { Concentration of } \\
\text { added standard } \\
(\mu \mathrm{g} \mathrm{mL}-1)\end{array}$ & $\begin{array}{c}\text { Final concentrationn } \\
(\mu \mathrm{g} \mathrm{mL}-1)\end{array}$ & $\begin{array}{c}\text { Concentration of } \\
\text { found standard } \\
(\mu \mathrm{g} \mathrm{mL})\end{array}$ & Recovery $\left.(\%)^{a}\right)^{-1}$ & $\begin{array}{c}\text { Mean percentage } \\
\text { recovery } \pm \text { RSD }\end{array}$ \\
\hline 25.00 & 15.00 & 40.00 & 15.65 & 103.03 & $100.74 \pm 1.55$ \\
25.00 & 25.00 & 50.00 & 24.91 & 98.86 & \\
25.00 & 35.00 & 60.00 & 35.32 & 100.34 & \\
\hline
\end{tabular}

${ }^{a}$ Each value is the mean of 3 determinations.

TABLE III - Parameters assessing the robustness of the method microbiologically

\begin{tabular}{lcccc}
\hline Variable & Range investigated & Norfloxacin $^{a}(\mathrm{mg} /$ tablet $)$ & Norfloxacin $^{a}(\%)$ & RSD (\%) \\
\hline \multirow{3}{*}{ Incubation time (time) } & $3 \mathrm{~h} 45$ & 372.48 & 93.12 & \\
& $4 \mathrm{~h}$ & 392.12 & 98.03 & 4.50 \\
\hline \multirow{3}{*}{ Wavelength (nm) } & $4 \mathrm{~h} 15$ & 407.57 & 101.89 & \\
& 525 & 397.12 & 99.28 & 2.27 \\
\hline
\end{tabular}

${ }^{a}$ Mean of 3 assays with 3 tubes in each 
TABLE VI - Assay results of norfloxacin by two different methods

\begin{tabular}{lcc}
\hline Day & HPLC (\%) & Turbidimetric (\%) \\
\hline 1 & 103.60 & 102.23 \\
2 & 102.41 & 102.12 \\
3 & 102.55 & 101.81 \\
Mean RSD (\%) & 0.11 & 0.21 \\
\hline
\end{tabular}

for quantitative determination of norfloxacin in the formulation studied. It is a useful analytical tool as a supplement for the physicochemical method. In addition, the turbidimetric assay can be carried out in just $4 \mathrm{~h}$, improving the time for routine analysis. Organic solvents are widely used in the pharmaceutical industry for many reasons, but with green chemistry and new technology the use of organic solvents is diminishing in this area. Therefore, this new methodology is very vital to the contribution of green chemistry and also to the health and safety of the analyst.

\section{ACKNOWLEDGEMENTS}

The authors are grateful to PACD-FCFAr-UNESP (Araraquara-Brazil), FAPESP process \# 2010/133352 (São Paulo-Brazil) and CNPq (Brasília-Brazil) for fellowships and União Química (Pouso Alegre-Brazil) for kind sample donations.

We also thank Jan Frommelt and Sucheta D'Sa by yours collaborations.

Competing interests: The authors have declared no conflict of interest.

\section{REFERENCES}

AGENCIA NACIONAL DE VIGILANCIA SANITARIA. ANVISA. Farmacopeia Brasileira. 5. ed. Brasília: Agência Nacional de Vigilância Sanitária, 2010. v.1, 267 p.

ALÉSSIO, P.V.; SALGADO, H.R.N. Development and validation of a successful microbiological agar assay for determination of ceftriaxone sodium in powder for injectable solution. Pharm., v.4, n.3, p.334-342, 2012.

BAKSHI, M.; SINGH, S. Development of validation stabilityindicating assay methods-critical review. J. Pharm. Biomed. Anal., v.28, p. 1011-1040, 2002.
BARAZA, A.M. Norfloxacin determination in nonaqueus media using perchloric acid. Rev. Farm. Bioquím. Univ. S. Paulo, v.21, p.141-146, 1985.

CARDOSO, S.G.; SCHAPOVAL, E.E.S. Microbilogical assay for terbinafine hydrochloride in tablets and creams. Int. J. Pharm., v.203, n.1-2, p. 109-113, 2000.

CAZEDEY, E.C.L.; SALGADO, H.R.N. Development and validation of microbiological agar assay for determination of orbifloxacin in pharmaceutical preparations. Pharm., v.3, n.3, p.572-581, 2011.

CHIERENTIN, L.; SALGADO, H.R.N. Development and validation of a simple, rapid and stability indicating high performance liquid chromatography method for quantification of norfloxacin in a pharmaceutical product. J. Chromat. Separation Techniq., v.4, n.2, p.171-175, 2013.

CORDOBA, B.M.; CORDOBA, D.M.; BERNABE, I. Determination of norfloxacin by fluorescence in the presence of different antacids: quantification of analytical interferences. J. Pharm. Biomed. Anal., v.14, n.8, p.977982, 1996.

DENG, B.; SU, C.; KANG, Y. Determination of norfloxacin in humam urine by capillary electrophoresis with electrochemiluminescence detection. Anal. Bional. Chem., v.385, n.7, p.1336-1341, 2006.

FARMACOPEIA Brasileira. 4. ed. Brasília: Atheneu, 2001. v.1, $163 \mathrm{p}$.

FERNANDES, P.G. Mode of action and in vitro and in vivo activities of fluoroquinolone, J. Clin. Pharmacol., v.28, n.2, p.156-168, 1988.

FROEHLICH, P.E.; SCHAPOVAL, E.E.S. Doseamento microbiológico do norfloxacino. Método da difusão em ágar (cilindros em placas). Rev. Ciênc. Farm., v.12, p.161165, 1990.

GU, K.J.; WU, X.M.; ZHAO, S.M.; TAO, Z. Fluoroquinolones determination of fluoride content in comparison. Chinese $J$. Pharm., v.25, p.448-452, 1994.

GUO, G.; PAN, W.; SU, D.; CHEN, H. Simultaneous determination of four fluoroquinolone residues in fish by ion-pair high performance liquid chromatography. Chinese J. Chromatogr., v.4, n.3, p.401-403, 2005. 
HEWITT, W. Microbiological assay for pharmaceutical analysis: a rational approach. Boca Raton: Interpharm/ CRC, 2004. 115 p.

\section{INTERNATIONAL CONFERENCE ON HARMONIZATION.}

ICH. Technical requirements for registration of pharmaceuticals for human use. ICH Harmonised Tripartite Guideline. Validation of Analytical Procedure: Text and Methodology. Q2 (R1). Switzerland: ICH Expert Working Group, 2005. 17 p. Available at: <http://www.bioforum. org.i1/Uploads/Editor/karen/q2_r1_step4.pdf > . Accessed on: 20 May 2014.

LIN, J.; ZEPING, R.; YUZHEN, H. Content determination of norfloxacin capsules by square wave polarographic. Chinese J. Hosp. Pharm., v.3, p.141-145, 2000.

LIU, W.; ZHANG, J.; ZHANG, C.; REN, L. Sorption of norfloxacin by lotus stalk-based activated carbon and iron-doped activated alumina: mechanisms, isotherms and kinetics. Chem. Eng. J., v.171, n.2, p.431-438, 2011.

LIU, Y.M.; JIA, Y.X.; TIAN, W. Determination of quinolone antibiotics in urine by capillary electrophoresis with chemiluminescence detection. J. Sep. Sci., v.31, n.21, p.3765-3671, 2008.

LU, Y.; LI, Y.; ZHAO, Y.; YANG, L.; JIANG, X.; WANG, Y.; WU, X. Research and application of fluorescence system on norfloxacin-terbium-phen-SDBS. J. Rare Earths, v.30, n.8, p.842-846, 2012.

PAVITHRA, B.H.; PRAKASH, N.; JAYAKUMAR, K. PK-PD modeling of norfloxacin after oral administration in rabbits. Vet. World, v.3, n.12, p.546-548, 2010.

PEDROSO, T.M.; SALGADO, H.R.N. Development and validation of a microbiological assay by turbidimetry to determine the potency of cefazolin sodium in the lyophilized powder form. Anal. Methods, v.6, n.5, p.1391-1396, 2014.
POHLHAUS, J.R.; KREUZER, K.N. Norfloxacin-induced DNA gyrase cleavage complexes block Escherichia coli replication forks, causing double-stranded breaks in vivo. Mol. Microbiol., v.56, n.6, p. 1416-1429, 2005.

SALGADO, H.R.N.; LOPES, C.C.G.O.; LUCCHESI, M.B.B. Microbiological assay for gatifloxacin in pharmaceutical formulations. J. Pharm. Biomed. Anal., v.40, n.2, p.443446, 2006.

SCHMIDT, C.L.; AGARRAYUA, D.A.; LAPORTA, L.V.; MACHADO, J.C.; MANFIO, M.L.; BITTENCOURT, C.F. Development and validation of a microbiological agar assay determination of cefuroxime sodium in pharmaceutical preparations. J. Microbiol. Methods, v.77, n.3, p. 308-315, 2009.

SHEN, Z.X.; WANG, J.; LIU, Z.Q. Determination of sodium and norfloxacin preparations. J. Pharm. Anal., v.13, p.107111, 1993.

SIMPSON, D.L.; KOBOS, R.K. Microbiological assay of antibiotics based on inhibition of ammonia production monitored with an ammonia electrode. Anal. Chim. Acta, v.164, p.273-277. 1984

UNITED STATES PHARMACOPEIA. USP35. National Formulary NF30. Rockville: United States Pharmacopoeial Convention, 2012.

TÓTOLI, E.G.; SALGADO, H.R.N. Development and validation of a rapid turbidimetric assay to determine the potency of ampicillin sodium in powder for solution for injection. Anal. Methods, v.6, n.5, p.5923-5928, 2013.

WELL, M.; NABER, K.G.; KINZING-SCHIPPERS, M.; SÖRGEL, F. Urinary bacterial activity and pharmacokinetics of enoxacin versus norfloxacin and ciprofloxacin in healthy volunteers after a single oral dose. Int. J. Antimicrob. Agents, v.10, n.1, p.31-38, 1998.

Received for publication on $10^{\text {th }}$ September 2014 Accepted for publication on $15^{\text {th }}$ June 2015 
